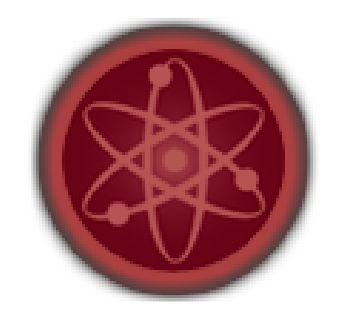

JUURNALRU

Рудаков О.M.

Вятский государственный университет

Россия, Киров

doi: 10.18411/1j2016-2-21

\title{
Анализ методов биометрической аутентификации личности
}

Современные информационные технологии не только обеспечивают новые возможности организации бизнеса, ведения государственной и общественной деятельности, но и позволяют обеспечить защиту конфиденциальной информации.

Основной задачей систем управления доступом к информационным ресурсам является предотвращение несанкционированного доступа к конфиденциальной информации или действия с информацией, нарушающие установленные правила доступа к информационной системе. Основной элемент защиты от несанкционированного доступа - процессы аутентификации и идентификации.

Традиционные методы идентификации личности, в основе которых находятся различные идентификационные карты, ключи или уникальные данные, такие как пароль, не являются надежными в той степени, которая требуется на сегодняшний день.

Сравнительный анализ показывает, что наиболее надежными системами контроля доступа к информации, в которых не используются карточки, ключи, жетоны, пароли и которые нельзя выкрасть или потерять, являются биометрические системы контроля доступа к информации. Раньше они в 
основном использовались в государственных учреждениях и там, где предъявляются особые требования к безопасности. В настоящее время биометрические системы контроля доступа к информации завоевывают популярность в банках, фирмах, связанных с обеспечением безопасности в телекоммуникационных сетях, в информационных отделах фирм.

Биометрия - это методы автоматической аутентификации человека и подтверждения личности человека, основанные на физиологических или поведенческих характеристиках. Примерами физиологических характеристик являются отпечатки пальцев, форма руки, характеристика лица, радужная оболочка глаза. К поведенческим характеристикам относятся особенности или характерные черты, либо приобретенные или появившиеся со временем, то есть динамика подписи, идентификация голоса, динамика нажатия на клавиши.

По сравнению с карточками, обычными ключами и другими носимыми идентификаторами, также кодами и паролями доступа, биометрическая идентификация имеет следующие преимущества:

- биометрические характеристики являются частью человека, поэтому их невозможно забыть или потерять;

• биометрический идентификатор невозможно передать другому лицу;

- существенно затруднена подделка «биометрического ключа»;

- бесконтактные биометрические технологии обладают повышенным удобством использования. [1]

Достоинства биометрических идентификаторов на основе уникальных биологических, физиологических особенностей человека, однозначно удостоверяющих личность, привели к интенсивному развитию соответствующих средств.

У всех биометрических технологий существуют общие подходы к решению задачи идентификации, хотя все методы отличаются удобством применения, точностью результатов. 
Любая биометрическая технология применяется поэтапно:

- сканирование объекта;

- извлечение индивидуальной информации;

- формирование шаблона;

- сравнение текущего шаблона с базой данных.[2]

Обычно биометрическая система состоит из двух модулей: модуль регистрации и модуль идентификации.

Модуль регистрации “обучает” систему идентифицировать конкретного человека. На этапе регистрации датчики сканируют человека для того, чтобы создать цифровое представление его облика. Специальный программный модуль обрабатывает это представление и определяет характерные особенности личности, затем создает шаблон.

Модуль идентификации получает биометрические характеристики и преобразует его в тот же цифровой формат, в котором хранится шаблон. Полученные данные сравниваются с хранимым в базе данных шаблоном для определения соответствия. Степень подобия, требуемая для проверки, представляет собой некий порог, который может быть отрегулирован для различного типа персонала, мощности компьютера, времени суток и ряда иных факторов.

В 21 веке есть достаточно много способов биометрической аутентификации. Все они делятся качественно на две большие группы: статические и динамические методы биометрической аутентификации.

Уникальные физиологические, или по другому статические, характеристики каждого человеческого организма, присущие только ему составляют основу статических методов биометрической аутентификации. Статические характеристики человека не меняются на протяжении всей его жизни и являются неотъемлемыми от него.

Динамические способы основываются на поведенческой (динамической) характеристике человека - особенностях, характерных для подсознательных 
движений в процессе воспроизведения какого-либо действия (подписи, речи, динамики клавиатурного набора).[3]

Общей характеристикой, используемой для сравнения различных методов и способов биометрической идентификации - являются статистические показатели - ошибки “первого" и “второго" рода. В биометрии наиболее устоявшиеся понятия - FAR (False Acceptance Rate) и FRR (False Rejection Rate). Первое число характеризует вероятность ложного совпадения биометрических характеристик двух людей. Второе - вероятность отказа в доступе человеку, имеющему допуск. Значения этих параметров для различных методов биометрической аутентификации приведены в Таблице 1.

Таблица 1- Характеристики FAR и FRR методов аутентификации.

\begin{tabular}{|l|l|l|}
\hline Метод & FAR & FRR \\
\hline Дактилоскопия & $0,1 \%$ & $3 \%$ \\
\hline Радужная оболочка глаз & $0,01 \%$, & $0,0001 \%$ \\
\hline Геометрия лица & $0,1 \%$ & $2,5 \%$ \\
\hline Геометрия кисти руки & $1 \%$ & $1,5 \%$ \\
\hline Рукописный почерк & $0,15 \%$ & $0,25 \%$ \\
\hline Голос & $3 \%$ & $8 \%$ \\
\hline Клавиатурный почерк & \multicolumn{1}{|c|}{$3 \%$} & $\mathbf{5 \%}$ \\
\hline
\end{tabular}

Раньше биометрические системы контроля доступа к информации в основном использовались в государственных учреждениях и там, где предъявляются особые требования к безопасности. В настоящее время биометрические системы контроля доступа к информации завоевывают популярность в банках, фирмах, связанных с обеспечением безопасности в телекоммуникационных сетях, в информационных отделах фирм. 


\section{Литература:}

1. Казарин М.Н. Разработка и исследование методов скрытного клавиатурного мониторинга: автореф. дис. канд. техн. наук; 05.13.19. /Таганрог, 2006.- 181 c.

2. Барабанова М.И., Кияев В.И. Информационные технологии: открытые системы, сети, безопасность в системах и сетях: Учебное пособие/ Барабанова М.И., Кияев В.И. СПб.: Изд-во СПбГУЭФ, 2010.- 267 с.

3. Иванов А.И. Биометрическая идентификация личности по динамике подсознательных движений: Монография./ Иванов А.И. - Пенза: Изд-во Пенз. гос. ун-та, 2000. - 188 с. 